\title{
DNA: let the public choose
}

Susan Wright, a historian of science at the University of Michigan, has followed the recombinant DNA debate closely. Here she comments on the recent public discussion of the revised NIH containment guidelines.

Much attention is currently being given to the concept of 'public participation' in policy decisions on technical and scientific matters. In referring to decisions on recombinant DNA research during a commencement address at the University of Michigan, Joseph Califano, Secretary of Health, Education, and Welfare, emphasised the importance of due process: "This means decisions made democratically through wide consultation, not by special elites". The tension in that statement, between "democratic" procedure and "consultation" (the results of which may still be digested by an elite group), points to a problem itself. Technical policy-making bodies are older than the growth of interest in participatory forms of decision making. They reflect an earlier faith in delegation of responsibility to high-ranking civil servants and expert advisors.

The political distance between current demands for participation in policy decisions on science and technology and the actual composition and procedures of policy-making bodies is nicely illustrated by the arrangements adopted by the NIH for decisions on recombinant DNA research. The elite nature of those arrangements was a principal subject of testimony at a hearing on proposed revisions to the NIH guidelines held at the Department of Health, Education, and Welfare in September before a committee chaired by Peter Libassi, HEW general counsel. NIH officials have claimed that all sectors have contributed to decisions on the guidelines through hearings and through the publication for comment of the guidelines, proposed revisions, and an environmental impact statement. However, testimony on the proposed revisions shows that many sectors see those procedures largely as a means for legitimising decisions taken within biomedical research circles rather than for facilitating participation in decisions.

The proposed revisions to the guidelines (10 August, page 411) are substantial: lowering of containment levels for many classes of experiment; exemptions which would take many experiments out of the guideline's control; and delegation of important responsibilities from NIH to local biohazards committees. Under the changes, local committees would be given wide responsibilities for recombinant DNA experiments. At a time when recombinant DNA technology promises to become as important for industry as it is for the universities, the revisions are a major step towards dismantling the central controls established two years ago.

All those who testified in support of the revisions were scientists and administrators with close ties to biomedical and agricultural research. Their reasons for approval were generally in line with those given by NIH director Fredrickson in his introduction to the guidelines. Delegation of authority to local biohazard committees was seen as a step in the right direction.

Critics of the proposed revisions included scientists and lawyers with ties to state and local government, trade unions, and public interest groups as well as to the universities. A concern expressed repeatedly at the hearing was that the circle of participation in decision-making has been largely restricted to a small group of scientists with close ties to NIH. According to Philip Bereano, a lawyer and professor in the University of Washington's Social Management of Technology Program, NIH decision making has been dominated by an "old-boy network"-a reflection, ultimately, of the basic conflict of interest of the NIH in attempting to regulate an activity that it also promotes. Bereano's claim was supported by data from an NSF-funded study of the composition of institutional biohazard committees (IBCs) reported by Nancy Pfund of Stanford University. Preliminary results show that the proportions of workers, students, and members without ties to the institutions doing the research averaged less than $2 \%$ and that almost $70 \%$ of the membership was drawn from scientists and administrators in such fields as microbiology, biochemistry and molecular genetics.

Witnesses noted that growing industrial interest in recombinant DNA means that the NIH advisory committee will be called on increasingly in the future to make policy recommendations with far-reaching social implications. Fredrickson's proposal to "broaden [the committee] modestly as needed for expertise" and "to include, perhaps, a dissenter from NIH policies" was seen as an inadequate response to those demands. In written and oral testimony, representatives of the Attorney General of New York State, the American Federation of Labor and Congress of Industrial Organisations, the Coalition for Responsible Genetic Research, the Environmental Defense Fund, and Friends of the Earth called for substantial expansion of the committee to include members of trade unions, public interest groups, public health organisations, and government agencies with potential regulatory jurisdiction. In addition, Friends of the Earth lawyer Richard Hartzman stated that the proposed changes were so sweeping that they required a new environmental impact statement.

The proposal to delegate responsibility for oversight to local institutions also received strong criticism. Pointing to violations of the guidelines that have occurred at Harvard Medical School and the University of California, San Francisco, commentators suggested that to respond to those events by enhancing rather than by checking responsibilities of local committees was inappropriate. "NIH proposes a form of enforcement which institutionalises conflict of interest and provides even less accountability for the Director of NIH and the IBCs than the previous guidelines," wrote Marcia Cleveland and Louis Slesin of the Natural Resources Defense Council. This matter is also of concern to Assistant Secretary of Labor Eula Bingham and Senator Adlai Stevenson, chairman of the Senate subcommittee on Science, Technology, and Space, both of whom have proposed retention of more centralised controls.

Critics have also claimed that the closed form of decisionmaking had affected the quality of the technical evidence used in reaching decisions. "There has been heavy reliance on unrefereed, unexamined reports of small committees meeting in private which are then presented as the consensus of the scientific community," said Jonathan King, associate professor of biology at MIT. He stated that the results from those meetings had been used in an "extraordinarily selective manner in which no arguments that countered or failed to support claims were either quoted or referred to."

How will the DHEW handle testimony on the revisions? Will a full environmental impact statement be necessary? Libassi after the hearing declined to say what he would do, but, echoing Califano's words, he did say that he thought the issues raised were "not ones to be decided by scientists." As to his own role: "A lawyer's skills can be applied in technical areas as well as procedural ones." Clearly, several government sectors and the public will follow closely how the sentiments of Libassi and Califano are translated in terms of expansion of the present circle of recombinant DNA decision-making. 